\title{
OPPORTUNITIES AND OBSTACLES OF AREA- BASED PARTNERSHIPS IN RURAL HUNGARY - MAIN FEATURES OF THE OPERATIONS OF LEADER LOCAL ACTION GROUPS BASED ON A NATIONWIDE SURVEY
}

\author{
Kis Krisztián - Szekeresné Köteles Rita
}

\begin{abstract}
Summary statements, conclusions, recommendations: Based on the results of our questionnaire survey, our study presents the major operational features of LEADER LAGs established in Hungary in the second half of 2007. Our national survey indicated that most of the partnerships established do not have experience in the implementation of community-based rural development programmes and there are no traditions and practices for development cooperation, which may cause problems as the success of programme implementation highly depends on the preparedness of local society, on the cooperation of local people.

The survey indicates that the development of areas covered by LAGs is hindered by so-called soft factors characterizing human resources (rural people and communities). Therefore human resources are not only factors of the rural economy but areas for development as well.

Having examined the tasks of LAGs, it can be established that they deem it to be their principal task to grant support funds. In our opinion, performance of this task is obviously necessary but far from sufficient to fulfil their catalyst role expected in local developments. For this purpose, it is essential for action groups to play a proactive role in organizing and thereby increase the capacity of local communities, a prerequisite for implementing a LEADER programme.

In accordance with the basic principle of subsidiarity, rural development should be implemented locally, managed by local communities, and decisions should be made at local levels in a decentralized manner. At the same time, the survey points out that LAGs operate under strong government influence and control, leading to the conclusion that the Hungarian practice of the LEADER programme is characterized by decentralization without subsidiarity.

In the present structure, the activities of LAGs are predominantly financed from central resources. Administration is the primary goal of their financing, which restricts their effective and efficient operations, thereby the successful implementation of the LEADER programme. It is unquestionable that LAGs need to be centrally financed since their operation is fundamental for programme implementation, but this requires more than acting in their present role of distributing resources.

In order for action groups to fulfil their real roles to boost local developments, they need to recognize their mission; and from the financing and regulatory side, they must be enabled to complete the tasks expected from them and their function.
\end{abstract}

Key words: endogenous development, Local Action Groups (LAG's), cooperation, social capital, capacity-building, subsidiarity, sustainability.

\section{Introduction}

Consequent upon and in order to offset the adverse effects of the significant social and economic changes and to meet new challenges in the rural areas of Western Europe in the 1980s and 1990s, demand rose for a new approach to rural development. As a result, EU rural development policies shifted towards endogenous development, as introduced into the practice of rural development in the framework of the LEADER programme. Due to the increased role of the LEADER approach in the implementation of rural development policies, local action groups came to play an important role in the institutional system of rural development. Through their activities to assist and promote local developments, they represent a spatial organization force in rural areas. Their activities can effectively contribute to the local implementation of European rural development policies, to the competitive and sustainable development of their region.

This paper studies the operational features, deemed to be important in our opinion, of LAGs established in Hungary under the auspices of the LEADER axis applicable between 2007 and 2013. Five areas are in focus which, in our opinion, significantly determine the operational efficiency and effectiveness of the LAGs involved in the study, and thus the implementation success of the LEADER programme in Hungary. Our study was prepared on the basis of the results of our almost totally comprehensive national questionnaire survey in March 2010, involving 94\% ( $=90$ ) of local action groups. 
The timeliness of the research is supported by the fact that the significance of applying the LEADER method is on the increase in terms of rural development in the EU. This is evidenced by the European Commission communication published on 18 November 2010 as regards common agricultural policy programming after 2013. When presenting the communication, EU commissioner for agriculture and rural development Dacian Cioloş stressed that "the new CAP will integrate the LEADER approach to an even greater extent" (EC, 2010). The topicality of the subject is also justified by the fact that consequent upon criticism on the operation of the programme in Hungary, such as anomalies concerning invitations for, submission and assessment of proposals, difficulties of proposal administration, and problems of operational financing, a social debate was initiated by the Ministry of Rural Development on 28 October 2010 in order to review the LEADER programme and transform it for a more efficient implementation.

\section{Theoretical background - the leader method in European rural development}

Earlier on, decision makers considered rural regions to be homogeneous areas where developments are determined by the same restrictive factors and opportunities. As the European Spatial Development Perspective (EC, 1999) pointed out, this approach is not in line with reality in the EU, as the characteristic of the European countryside is varied and diverse, which appears in the diversity of people and the communities as well as nature, landscape and activities. Consequently, development possibilities and trends of rural areas represent significant differences. All this makes it necessary for development programmes and measures to take local features and specificities into consideration. Accordingly, different means and different policies must be applied for their development. According to Szörényiné Kukorelli (2005), high levels of differentiation in rural areas contributed to the evolution of the characteristically European model of rural development as mentioned above in the 1990s, promoting local developments by introducing bottom-up policies. Consequently, sustainable rural development based on local consensus can only be realized by strengthening local society, by increasing its ability to assert interests; therefore solutions and strategies to boost the above are required to be implemented. An innovative solution for this is provided by the LEADER programme called into life by the European Commission, the principal feature of which is an approach of so-called endogenous development based on internal resources and local communities in a bottom-up arrangement. According to Barke and Newton (1997), endogenous development is a process, which includes the mobilization of the local community. It requires an organizational structure which brings together different interests to achieve common goals, a locally agreed strategic planning process and an agreed allocation of resources with the specific purpose of developing local capacity in terms of skills and competencies. In conformity with the above, the main objective of the LEADER programme is to build on the internal resources of small regions and support the population living there in considering their longer-term development opportunities and implementing plans designed in collaboration. In accordance with the principle of subsidiarity, a development programme is to be designed and managed by development groups (local action groups) established at small region level, coordinating the representatives of entrepreneurs, NGOs and the public sector by involving the population living there.

Thus, LEADER breaks away from centralized, centrally managed, top-down support systems, one of the specificities of which is that local problems, opportunities and solutions are not known at a central level, therefore in many cases they do not offer real roads for development as they do not enable the implementation of development programmes based on local needs. Kovách (2000) states that the LEADER approach is a new enhanced model of rural development policy attempting to replace hierarchic interventions by a system of local developments primarily characterized by local involvement and partnership. In this interpretation, LEADER is a way of reforming European rural development, qualifying LEADER as the essence of EU rural development policies.

\section{Material and method}

The survey serving as a basis for our study was conducted in March 2010. The questionnaire including 70 questions was sent to each community with the title LEADER LAGs as of 26 September 2008, assisted by the staff of the Rural Development Division of the Ministry of Rural Development (Ministry of Agriculture and Rural Development at the time of the research). The rate of response (94\%) was highly favourable: 90 out of the 96 questionnaires sent out were returned. Our survey primarily focussed on the establishment of LAGs, their operations, tasks, and the features of the area covered by them. This study involves only some part of the questionnaire survey and answers are sought for the following questions:

1. Does the area have a history of community controlled (LEADER-type) rural development?

2. What are the main obstacles / hindrances to the development of the areas covered by LAGs?

3. What are the main tasks of LAGs in the successful implementation of the LEADER programme?

4. To what extent has the principle of subsidiarity been realized in the operations of LAGs, and to what extent are decision making and responsibilities decentralized to a local level?

5. Would LAGs survive if LEADER programme funds ceased to exist and what secure sources of income could be counted on if central financing was discontinued? 


\section{History of community controlled (LEADER-type) rural development in the areas covered by the action groups}

The LEADER programme offers an efficient method for the implementation of rural development at local levels; however, participation, cooperation and coordination are definitely required in order for this model of rural development to be operative and successful.

According to Ray (1999), the endogenous development approach can be put into practice on the basis of already existing territorial organizations or ones newly established for this purpose. In this context, it is important to note that the LEADER groups or LEADER areas where is no tradition of participation and / or do not have the practical application of relevant knowledge and skills of the LEADER method, increased capacity-building and more intensive animation, mentoring is needed (Commins and Keane, 1995). In our survey, 75 of the responding communities were newly established and started to operate in this programming period, during 2007, in the course of the process of registration and institutionalization preceding planning. The remaining 15 action groups had been established previously, in an earlier programming period. So the majority of action groups are ad hoc organizations, instituted for using the resources available in the period 2007-2013. A smaller part of them joined in the local-level implementation of the objectives of the fourth-generation LEADER programme as already existing partnerships.

71 out of the action groups studied had a history of some sort of community-controlled rural development programme implementation, while 19 partnerships do not have any such experience. $30 \%$ of the settlements covered by current action groups was covered earlier by communities established in the framework of AVOP LEADER+. For 1 action group, the settlements involved completely tally with the current settlements; for 18 communities, settlements absolutely differ from earlier settlements; and for 54 action groups, settlements partly overlap with earlier ones. Furthermore, $13 \%$ of members of the action groups studied had been involved in the work of communities established in the framework of the LEADER+ programme.

Based on the above, it can be established that the majority of the partnerships established do not have any experience in the implementation of community-based rural development programmes, with no traditions and practice in development cooperation. This may pose a problem as the success of programme implementation greatly depends on the preparedness of local society, on the cooperation of local people and organizations.

At places with longer-term experience in the implementation of such developments or with a history of cooperation and self-organizing activities, there are higher standards of participation, eagerness to cooperate, and agility to act, thereby improving development efficiency and contributing to successful programme implementation.
It should be noted that where there are greater traditions of civil values, mentality and behaviour (independence, selfconsciousness, sense of duty, commitment, morality, conscience, responsibility for the community etc.) it is less difficult to implement developments compliant with the basic principles of the programme. At many places, however, experience shows the contrary since disrupting forces are stronger than connecting links, with no managing and cementing force to play a dominant role in uniting local players and capable to establish social cooperation for mutual benefits.

All this means that the majority of action groups would have needed a longer period of preparation, as LEADER - by nature - can only contribute to rural area development if local communities are duly prepared and have the skills to enable them to define their common objectives, to deploy the resources required, and to solve their own problems in common (in community).

So the quality of local society is of great importance, therefore it is crucial to develop local communities and to encourage the operations of social organizations. Fehér (2005) is also of a similar opinion, stating that rural communities, human relations and the social capital embedded in them represent an important resource for rural area development. The same is stressed by G. Fekete (2005), stating that in order to set rural areas on a development path, it is essential to substantially improve the self-organizing and interest enforcement capacities of the population living there.

At the same time, this is a process which contributes to the realization of objectives, but the time required therefore must be taken into consideration since it takes much time even decades - to substantially change and alter social conditions. Where there is no precedent of development based on cooperation, skills development and capacity building require even more time and attention than at places where the local community is experienced in rural development based on participation and cooperation.

Therefore the establishment of LAGs represents an absolutely necessary but by no means sufficient condition for the local-level implementation of the LEADER programme, especially if their establishment was not certainly voluntary in all cases. The article by Sándor Németh also calls attention to this, stating that Local Rural Development Offices and office managers "not only and simply coordinated the establishment of LEADER communities but practically they were the ones to establish them" (Németh, 2009). The foregoing question the reason for existence of LAGs in some sense and forecast their operational efficiency.

\section{Factors to hinder the development of regions covered by lags}

In the course of rural area development, properties, conditions, opportunities and demands must certainly be taken into consideration, and they must all be taken into account for developing a strategy to improve the life quality 
of the population living there. However, the realization of rural development objectives is prevented or hindered by a number of factors connected to the diversified social and economic situation and environmental conditions characteristic of rural areas. It is essential to know these factors or bottlenecks as problems must be identified and evaluated in a proper context to find the right path to follow. Based on this information and knowledge, a realistic concept / development plan can be specified with the main objective to improve the life quality of rural people.

In order to identify the factors mostly hindering the development of LEADER regions, the heads of LAG organizations were asked to rank the factors relevant for their region in order of importance, choosing from the 16 options below (with 1 indicating the most important factor to hinder the development of a given region). Table 1 shows the results of the survey.

Table 1. Order of importance of the factors hindering the development of areas covered by LAGs

\begin{tabular}{|c|l|c|}
\hline Serial no. & \multicolumn{1}{|c|}{ Hindering factors } & Average score \\
\hline 1 & Lack of capital & 1.8 \\
\hline 2 & Lack of funds for support & 2.7 \\
\hline $\mathbf{3}$ & Lack of willingness to cooperate & $\mathbf{3 . 4}$ \\
\hline 4 & Underdeveloped infrastructure & 3.6 \\
\hline $\mathbf{5}$ & Lack of knowledge & $\mathbf{3 . 6}$ \\
\hline $\mathbf{6}$ & Lack of interest & $\mathbf{4 . 2}$ \\
\hline $\mathbf{7}$ & Lack of innovativity & $\mathbf{4 . 3}$ \\
\hline 8 & Regulatory restrictions & 4.7 \\
\hline $\mathbf{9}$ & Lack of confidence & $\mathbf{4 . 7}$ \\
\hline $\mathbf{1 0}$ & Lack of key people & $\mathbf{4 . 7}$ \\
\hline $\mathbf{1 1}$ & Lack of information & $\mathbf{5 . 0}$ \\
\hline 12 & Adverse geographic conditions & 5.7 \\
\hline 13 & $\begin{array}{l}\text { Political situation in the broader region or } \\
\text { nationwide }\end{array}$ & 5.9 \\
\hline $\mathbf{1 4}$ & Lack of commitment & $\mathbf{6 . 4}$ \\
\hline 15 & Local political conditions & 6.6 \\
\hline 16 & Unfavourable natural endowments & 7.0 \\
\hline
\end{tabular}

Source: Own data collected.

In our opinion, the following - so-called soft - factors can be highlighted in connection with the basic principles and philosophy of the LEADER programme, with a view to the efficiency and success of programme implementation (see in bold in the table): presence or absence of a willingness to cooperate, confidence, knowledge and information, lack of interest, innovativity, key people, and commitment.

Cooperation and the willingness to cooperate play a significant role in the development of rural areas. This particularly applies to LEADER-type developments, one of the basic components and basic tenets is cooperation. People's ability to cooperate is coupled with the generation of social capital. Social capital is generated when people's relationships change in a way to facilitate action. Social capital is a resource for communities and partnerships, as well as an indicator of relations and cooperations established in society and the economy. Following from the above, social capital is a measure of relatedness within a community or society, and as such, it demonstrates cohesion in a community and the society, which is manifested in the connections, norms, confidence, and cooperation of people and communities for common interests and benefits. According to Coleman (1998), social capital is a "productive" resource, which allows certain otherwise unattainable goals. This form of capital takes shape in the structure of relations between actors.

Cooperation is nothing but a system of relations between people (individuals) and organizations) with the purpose of realizing mutual benefits and advantages. In our case, the main objective is to improve the life quality of rural people, and the LEADER programme offers a framework for this.

Cooperation and confidence constitute a closely related system as cooperation is based on confidence. It is a common experience that we are ready to cooperate if we trust each other, whether another person or an organization. Accordingly, the main obstacle to the establishment, development and subsistence of cooperations is a lack of confidence, to be traced back to various reasons (disappointment, lack of knowledge and information, etc.)

The success of the adaptation of rural areas highly depends on the preparedness of stakeholders. In this respect, the presence or absence of knowledge and information should be highlighted. In the era of knowledge-based societies, up-to-date, properly utilizable and convertible knowledge has been revaluated. This means that the quality features of human resources (qualifications, expertise, motivation, working style and morale etc.) are emphasized as opposed to quantity features. Accordingly, knowledge, skills and abilities have a greater impact on the development of regions than earlier. Information influences the decisions and actions of people and organizations, thereby influencing the functioning of the economy and society, and consequently spatial development. Therefore, information - its presence or absence (under-information) is a considerable differentiating factor, at the level of both local players and different areas as well. Thus, information flow - communication - plays a really important part in improving the level of preparedness on individuals and their communities.

People's lack of interest in community issues - and bottom-up rural development is really like that - can be traced back to several reasons, including disappointment, lack of confidence, and lack of knowledge and information. A lack of interest in public affairs affects civic activity and social inclusion, which is not favourable to the establishment and development of cooperations, specially significant for our topic. This sets back social competitiveness and social sustainability is questioned in the shorter or longer term. In the course of the design and implementation of bottom-up community-controlled (rural) development programmes, individual and community initiatives are highly important. 
However, there should be communities first of all in order to be able to talk about community initiatives. Acceptance of community values and interests and identification with them plays an important part here, requiring dialogue, communication, proper information flow, increasing knowledge, acceptance of others, confidence, mutuality, and a willingness to act, in order to be able to improve and develop the ability of the community to take initiatives, take action, and assert interests. It serves as a basis for enabling people and their communities to delineate their future and take action to make it come true.

Perpetual social and economic changes require the players of spatial processes to adapt on an on-going basis, which is only ensured by invention and renewal. And the basis for such renewal is innovation, that is, the ability and sensitivity to innovate. Innovation - representing new ideas, new resource combinations, new organizations, new activities, new products, and new human and community behaviours - can concern products and activities, but innovations can also prevail not only in the economy but in the social and political sector as well. Innovations are phenomena or objects different from previous ones, arising from changes and transformations thereof. By adapting them, recipients will act presumably at higher levels (Rechnitzer, 1994). Therefore, innovations and innovativity provide considerable competitive advantages to settlements and regions.

Kovács (2003) points out that the role of innovative individuals capable of modernization (innovative managers, smart entrepreneurs) and communities able to assert their interests has increased in local developments. It is important to note in this respect that rural development is not (primarily) a technical or economic issue - at least in terms of conditions -, but it principally involves the agitation of human powers to give impetus to stuck developments (Font, 1998). This requires leadership because thereby society can be mobilized and encouraged for action, the relationships and activities of local players can be organized, resulting in local communities' increased ability to act. Leadership can be provided by all the people, entrepreneurs, municipality bodies and NGOs promoting local interests and committed to the sustainable development of their community based on cooperation (Kis-Szekeresné, 2008).

It is indicated by the foregoing that factors are not independent of each other: many times, they exert a negative impact on spatial development - or a positive one in the event of their change to the better - in a complex manner, together and in interaction. Based on the causal principle of cumulative circulation, social and economic processes react upon the factors affecting them, resulting in more unfavourable processes in the case of adverse tendencies. So, human resources - that is, rural people and their communities - play an important role in the adaptation process of rural areas. It can be observed at the same time that human resources are not only factors of the economy of rural regions but areas for development as well.

\section{Duties of lags in competitive and sustainable rural development}

In the framework of the LEADER programme, important elements of the institutional system enforcing rural development policies include LAGs - organizations for development established in rural areas throughout Europe -, intended to elaborate and implement strategies for sustainable development. As a consequence of the above, LAGs play an important role in the local level implementation of rural policy objectives. However, in conjunction with strategy implementation, the role of LAGs in the efficient use of funds is not ended by planning / drawing up development strategies for (small) regions. As funds are used, specific activities and developments are realized at a project level, local players' capacity building and agility to act are required to be boosted in order to provide a basis for the successful and efficient use of development funds. Thus, efficient strategy implementation and furthering the development of a given rural area requires on-going active work, in the course of which LAGs must become real organizing forces in the development of their region.

In the national survey, we collected those tasks and duties that - in our opinion - LAGs should undertake in order to meet the challenge above and become real organizing forces in their region. As regards this issue, action groups were requested to evaluate their tasks by importance, along a scale of 1 to 9 (with 1 indicating the most important and 9 the least important task). Based on the survey results, LAGs specified the order of importance of the duties to be performed by them as set out in Table 2.

Table 2. Duties of LAGs in the order of importance specified by them

\begin{tabular}{|c|l|c|}
\hline Serial no. & \multicolumn{1}{|c|}{ Description } & Average score \\
\hline 1 & Provide and grant funds for support & 2.2 \\
\hline 2 & $\begin{array}{l}\text { Boost local economies through } \\
\text { information flow }\end{array}$ & 2.9 \\
\hline 3 & $\begin{array}{l}\text { Strengthen territorial relations, partnership } \\
\text { building among local players (bring local } \\
\text { players together) }\end{array}$ & 3.3 \\
\hline 4 & $\begin{array}{l}\text { Encourage local players to create joint } \\
\text { projects / multisectoral activities; elicit } \\
\text { synergies }\end{array}$ & 5.1 \\
\hline 5 & \begin{tabular}{l} 
Capacity building of local players \\
\hline 6
\end{tabular} & $\begin{array}{l}\text { Provide opportunities for consultation / } \\
\text { exchange of opinions }\end{array}$ \\
\hline 7 & $\begin{array}{l}\text { Disseminate the concept of sustainable } \\
\text { development, encourage its putting into } \\
\text { practice }\end{array}$ & 5.3 \\
\hline 9 & $\begin{array}{l}\text { Share and spread best practices } \\
\text { in other regions }\end{array}$ & 6.9 \\
\hline
\end{tabular}

Source: Own data collected.

The survey points out that action groups deem it to be their most important task to finance proposals and to grant support. In our opinion, the role of action groups in the implementation of Local Rural Development Strategies 
cannot be restricted only to the distribution of the development funds coordinated by them: their operation spans over a much wider range of activities in which the mobilization of local communities, partnership building, generation of cooperations, skills development, promotion of sustainable development, and endeavours to interlink developments for complexity should appear as important aspects. Actually, efficient strategy implementation requires an increase in the agility and cooperation of local players, necessitating the completion of a variety of tasks.

The LEADER programme cannot be realized successfully without involving and mobilizing local communities. Therefore it is deemed to be one of the important tasks of LAGs to address the local community and to encourage them for action. Thereby a better and more realistic vision can be produced to better serve the catching up of regions and the improvement of the life quality of the people living there.

Communities can be involved, participation can be ensured in various forms, in the interest of which LAGs can apply a variety of means and methods, including community meetings, consultations, discussions, workshops, and events. Reputed key people held in general esteem can also be mentioned. Local communities can also be involved through NGOs as they provide an appropriate framework and opportunity for the selforganization and active presence of citizens. In addition, different surveys can also be conducted to provide opportunities for expressing opinions. The foregoing contribute to a wideranging assessment of the necessities and development needs of local players. In this respect, Lukovich (2004) stresses that participation helps to explore problems and potentials since participation may assist in the collection of many types of data; at the same time, it is the only source of information containing the wishes, opinions and value systems of individuals. Besides simply ensuring participation, it is important for LAGs to mobilize both community and actors and urge them for thinking together. It is also important to ensure programme publicity to achieve broader participation and to mobilize the community, together with presentations on the activities of LAGs and circulation of information related thereto in local and regional media. For this purpose, information packages can be compiled and published e.g. through publications, the community homepage, leaflets and placards.

Local cooperations and partnerships are important for the implementation of rural development based on participation as they play a dominant role in assisting local development work. Without cooperations and partnerships social capital in fact -, local developments cannot be effective and cannot lead to the expected results, therefore establishment and extension thereof poses a key challenge to LAGs. Social capital can be employed and used as a real resource on the basis of the cooperation of the parties. Cooperation enables the inclusion of social capital - as a resource instrumental to action - in spatial processes, thus creating a new combination of resources which may greatly contribute to the success of the LEADER programme and to the development of settlements and areas affected by LAGs on the basis of internal resources.
It is important to stress that rural development, as well as local development is a process as a result of which the objectives set can be realized. In our opinion, the process itself is at least as important in the course of the implementation of the LEADER programme as measurable and quantifiable results. The proactive operations of LAGs, their activities to organize local society greatly contribute to improving the capacity of self-organization and interest assertion of the population living there, consequently to strategy implementation.

Particularly important elements of endogenous developments such as LEADER are capacity building and community development (Shortall and Shucksmith, 2001), resulting in an increased capacity of the community to act and assert its interests. Capacity building is a process where individuals, groups, organizations, institutions and societies develop their abilities individually or collectively in order to perform a variety of tasks, to solve problems, to set and realize objectives (Kumin, 2006). According to Shucksmith (2000) the essence of capacity-building is the creation of social capital that could benefit the whole community. Therefore capacity building appears as a process which should necessarily precede and complement local development strategy design and implementation. A basic component of the LEADER philosophy is trust in local communities that they can solve their own problems in a community arrangement. However, this necessitates capacity building in the population and organizations of the region to enable them to do so. Capacity building can include a variety of activities, such as training for participants and stakeholders, assisting the flow of information between them, improving communication, encouraging connections, encouraging thinking differently, establishing norms and values, presenting on the advantages and opportunities of cooperation, etc. As a result of capacity building, local communities become more active in the processes of programming, strategy development, and implementation as well. It is a tool to achieve that social changes efficiently assist the realization of economic objectives, enabling more productive and efficient development work. As a consequence of the foregoing, LAGs as internal development factors can play an important role, through their capacity development activities, in influencing local development processes, in making them more dynamic, which will strengthen their position within the institutional system of rural development.

Networking and keeping contacts with local and extralocal players involved and / or interested in development is related to the performance of a variety of tasks by LAGs, providing a basis for cooperations between partners. These activities contribute to a more efficient information flow and dissemination; to the transfer of best practices and experience; to the spread of innovation; and to the stimulation of cooperations.

In spite of the fact that networking is the least important task performed by action groups, 80 per cent of the LAGs in our survey said that they cooperated with other action groups 
in the country and 40 per cent thereof that they were involved in transnational cooperation. LAGs specified 44 areas for cooperation with Hungarian action groups and 30 where the partner is from abroad. In each case, cooperations are arranged around a specific task or problem, such as environment protection, preservation of traditions, innovation, tourism development, local products, enterprise development etc. Networks thus established play an important role in the flow of information of diverse content and significance.

In respect of networking, an important task of LAGs is to disseminate best practices from the region and outside, together with encouraging their adoption and use. Best practices include novel and bold solutions not yet tried and tested which "work". These good or exemplary solutions and developments can serve as a lesson, can provide guidance in answering "what, how and why" questions (in the design of future developments and effective implementation thereof), thereby providing assistance in the realization of successful developments. However, this requires information flow and information transfer since no experience can be utilized without it. Obviously, it is necessary to analyze these practices, to study their exemplariness and applicability.

The concept of sustainability and sustainable development - stressing the coordination of economic, social and environmental considerations - is an indispensable basic principle of all developments in the 21st century, including rural development. In this respect, it is important to utilize resources in a sustainable, that is, socially useful, economically reasonable, and ecologically acceptable manner (Fehér, 2005), based on behaviours complying with the concept and notion of sustainability. Acceptance of values and interests and identification with them plays an important part in this. The same is supported by the following chain of thought as well, stating that sustainability is nothing but "... a way of looking at things, a way of thinking, a way of life, a way of production and a way of consumption ..." (Csete, 2005). LAGs definitely play a role in forming attitudes to serve as a basis for sustainable development.

\section{Lag operations and prevalence of the principle of subsidiarity}

The basic principle of the concept and practice of the LEADER programme is subsidiarity, that is, the decentralization of decision-making and control, enabling participation, the mobilization of local resources, coordination of local conditions and needs with developments, and their efficient implementation.

In his encyclical letter commencing by Quadragesimo anno, Pope Pius XI presented subsidiarity as one of the most important basic principles of social philosophy. According to the compendium of the social teachings of the Church, a special consequence of subsidiarity is participation, expressed in acts whereby citizens contribute to the cultural, economic, social and political life of their communities individually or in cooperation with others, directly or through their representatives (Az igazságosság..., 2007).

The significance of subsidiarity as a basic principle of rural development is emphasized by the declaration issued as a final document of the rural development conference held in Cork in 1996. The declaration provides a basis of integrated, holistic approach to rural development principles on the model of LEADER. Rural development must be local and community-driven within a coherent European framework. Decision-making must be decentralized, so decisions must be made at local level, with the cooperation of stakeholders. The emphasis must be on participation and a bottom up approach (EC, 1996). So, the principle of subsidiarity means that decisions and implementation must be placed to the local level - in our case, to the level of LEADER areas - with the greatest insight and competence in completing the task. According to Barke and Newton (1997), the most important element of the implementation of the LEADER programme are LAGs, serving as a means for decentralized development. However, well-prepared professionals with appropriate capacities, and active local society ready to cooperate are required for the proper completion of tasks. At the same time, decentralized financing and control necessitates close cooperation between local partnerships (LAGs) and programme managers, in the course of which subsidization, that is, assistance is in focus.

The question arises whether local action groups have competences at a degree expectable from applying the principle of subsidiarity, that is, spheres of authority and competencies in decisions on local developments.

As regards subsidiarity, Hungarian LAGs were asked in our questionnaire survey to evaluate the following on a 1 to 5 scale:

1.) To what extent the principle of subsidiarity prevails (local-level decision making and control) in their work;

2.) To what extent the managing Authority and the Intermediary Body are characterized by conduct in compliance with the principle of subsidiarity, that is, to what extent the decentralization of decision making and the actual realization of local control and management are facilitated;

3.) To what extent can LAGs assert their interests at higher levels of the institutional system of rural development, that is, whether there is a one-way or a two-way relationship and / or communication between the centre and the locality. The average score for the first question was 3.5, meaning that some of the decisions are made at local level; LAGs' independence is restricted in terms of decision making; and central control prevails. The average score for the second question was 3.1, indicating that the higher-level organizations of the institutional system of rural development do not make sufficient efforts to facilitate the decentralization of decision making. The foregoing is confirmed by the average score of 2.9 for the third question, meaning that LAGs 
believe that central intentions are mainly enforced in the communication between the different levels, with them mostly playing the executive role.

This is contrary to the principle of subsidiarity, that is, enforcement of the decentralization of decision making and responsibilities to local levels, as LAGs are subject to strong government influence and control as opposed to LEADER's basic principles of community decision making and control. Based on the foregoing, the conclusion can be drawn that the Hungarian practice of implementing the LEADER programme is characterized by decentralization without subsidiarity. LAGs - as local tiers of the decentralized institutional system - have been established, but in the course of their operations decision making is not delegated or only to a minor extent; local partnerships' capacities to assert their interests are curtailed, as manifested in the limited cooperation between control levels. Thus, theory and practice become detached from each other, restricting the evolution of local communities and the realization of the potential achievements of community-based development work. Kovách (2000) is of the same opinion, stating that the institutionalization of bureaucratic control goes contrary to the partnership principle and impairs the chances of rural areas for catching up. According to Shortall and Shucksmith (2001), LAGs - as decentralized rural development partnerships - represent new forms of local decision making and control, the efficient operation of which certainly requires a well-defined and transparent regulatory framework and a coordinated institutional structure. In the absence thereof, the status of LAGs becomes insecure and they will not be able to perform the duties expected of them in the promotion of local developments.

The foregoing indicate that an essential pre-requisite for applying the LEADER approach is the central power acting to assist and encourage local developments. So it is important to note that the operation of LAGs and the success of employing the LEADER method highly depends on the legislative and regulatory as well as cooperation and coordination roles of the Ministry supervising the implementation of the rural development programme (Ministry of Rural Development) and of the intermediate body (Agriculture and Rural Development Agency).

\section{Financing and sustainability of lag operations}

Similarly to other organizations, the stable operation and the high-standard completion of the functions and duties of local action groups require appropriate financing, a reliable financial background. An important component thereof is the acquisition and realization of income sources of appropriate volume.

LAG operations are financed in a subsequent payment scheme using central funds. Action groups were allowed to plan their own operating costs drawing on centrally allocated funds, to implement their Local Rural Development Strategies, subject to the proviso that in the case of Axis III measures, up to 15 per cent of the amount available, and in the case of LEADER funds, up to 20 per cent thereof may be allotted to their operating costs. Accordingly, action groups have an average 385 million HUF to operate on (Németh, 2009). A background study completed by the LEADER Working Group in 2010 points out that the minimum amount of funding required for the operation of LAGs is 160 million HUF in the period 2008-2015, which is considerably higher in the case of action groups covering larger areas. According to the study, there are 10 LAGs where the funding granted for operations will surely be insufficient for the entire period of operation and in case of another 11, the sufficiency of funding is questionable (LEADER Working Group, 2010).

Based on the survey of the situation it can be stated that it is not realistic for LAGs to finance their operating costs from other sources of revenue; at the same time, most of the funds to be allotted for operation is used for applications management and administration, which does not make it possible - or at least makes it much more difficult - to perform other tasks. All this makes it dubitable for action groups to achieve their goals and to become real internal development factors within their region, not only to act as distributors of funds.

As indicated by the foregoing, financing of LAG operations is governed by central funding; other sources of revenue are not or only scarcely available. This revenue structure shows that the operation of action groups highly depends on the availability of central funds and the criteria for their utilization.

As regards financing and the sustainability of operations, LAGs were questioned whether the action group would subsist if LEADER operating funds were ceased to be granted, whether this work organization could further function under such circumstances. 65 out of the 90 responding action groups said that their LAG would surely be dissolved without funding as it could not finance its operations from other sources. 24 action groups answered that their activities would be considerably restricted in the absence of central funding, but they would not be wound up; and there was only one to surely survive as funding for operations could be secured from other sources. Survey results again highlight the strong dependence of LAG operations on central funding, the strained financing conditions of LAGs.

It can be clearly stated that in the event of the depletion of central sources of operational funding, all LAGs but one would surely be unable to continue the operation of their work organizations, which would jeopardize the implementation of Local Rural Development Strategies, thus that of complex rural development measures in Hungary. Therefore it is definitely required to review the financing structure of action groups in conjunction with a reconsideration of the regulation of their activities.

Further on, action groups were requested to mark those of the optional answers specified in connection with the sustainability of their financing and operations wherefrom they could expect secure revenues in case of central funding 
coming to an end. In the absence of LEADER funding, other sources indicated for sustaining operations included membership fees for the most (64), then project proposal funding (38), and thirdly, revenues from entrepreneurial activities (21). 16 action groups would expect to receive municipality funding, and also 16 would expect revenues from offerings of 1 per cent PIT and amounts raised through programmes and publications, respectively. Finally, 13, 6 and one of the action groups indicated that they could expect to be funded by their members, external parties, and businesses, respectively. The latter figures give food for thought as they clearly reflect the repute and recognition of the activities of action groups, and in conjunction therewith they show how action groups are socially embedded.

It follows from the foregoing that the way and the amount of funding obtained for functioning is a critical issue in the operation of action groups. It is unquestionable that they need to be financed as the operation of LAGs is essential for the implementation of the LEADER programme. However, this requires more than the current activities related to the distribution of funding: action groups must recognize their mission, and they must be enabled from the financing and regulatory side to perform their duties and functions and really act as catalysts of local development.

\section{References}

(1) Az Igazságosság és Béke Pápai Tanácsa (2007): Az egyház társadalmi tanításának kompendiuma (Ford. Dér K. - Horváth P.). Szent István Társulat, Budapest. 433. p.

(2) Barke, M. - Newton, M. (1997): The EU LEADER Initiative and Endogenous Rural Development: the Application of the Programme in Two Rural Areas of Andalusia, Southern Spain. Journal of Rural Studies, Vol. 13. No. 3. 319-341. pp.

(3) Coleman, J. S. (1998): Gazdasági tőke, kulturális tőke, társadalmi tőke. In: Tőkefajták: A társadalmi és kulturális erőforrások szociológiája (Szerk. Lengyel Gy. - Szántó Z.). Aula Kiadó, Budapest. 11-43. pp.

(4) Commins, P. and Keane, M. (1995): Developing the Rural Economy - Problems, Programmes and Prospects. National Economic and Social Council, Dublin. 264. p.

(5) Csete L. (2005): Az agrár- és vidékfejlesztés fenntartható rendszere. Gazdálkodás, 49. évf. 2. sz. 3-15. pp.

(6) EC (2010): A közös agrárpolitika 2013 utáni időszakra szóló, előretekintő programterve. IP/10/1527. Brüsszel, 2010. november 18. http://europa.eu/rapid/pressReleasesAction. do? reference $=I P / 10 / 1527 \&$ format $=P D F \&$ aged $=0 \&$ language $=$ HU\&guiLanguage $=$ en
.(7) EC (1996): The Cork Declaration - A Living Countyside. The European Conference on Rural Development. Cork, Ireland. 79 November, 1996. http://europa.eu.int/comm/agriculture/rur/ cork en.htm.

(8) EC (1999): European Spatial Development Perspective: towards balanced and sustainable Development of the territory of the European Union. European Commission, Luxembourg. 87. p.

(9) Fehér A. (2005): A vidékgazdaság és a mezőgazdaság. Agroinform Kiadó, Budapest. 336. p.

(10) Font E. (1998): A vidék gondja globális vagy lokális kérdés? A falu, 13. évf. 3. sz. 27-35. pp.

(11) G. Fekete É. (2005): A magyar vidék önszerveződő és érdekérvényesitő képessége. In: Új vidékpolitika (Szerk. Glatz F., 2008). MTA Társadalomkutató Központ, Budapest. 241-242. pp.

(12) Kis K. - Szekeresné Köteles R. (2008): A negyedik generációs LEADER-tervezés tapasztalatai a Hódmezővásárhelyi kistérségben. A falu, 23. évf. 3. sz. 17-29. pp.

(13) Kovách, I. (2000): LEADER, a New Social Order, and the Central- and East-European Countries. Sociologia Ruralis, Vol. 40. No. 2. 181-189. pp.

(14) Kovács T. (2003): Vidékfejlesztési politika. Dialóg Campus Kiadó, Budapest-Pécs. 284. p.

(15) Kumin F. (2006): Kapacitásépítés - új törésvonalak a világgazdaságban. Világosság, 47. évf. 5. sz. 57-66. pp.

(16) Leader Munkacsoport (2010): A 2010. július 15. és 2010. augusztus 31. között müködő LEADER Munkacsoport háttértanulmánya a LEADER program egyszerüsítésére, okszerüsítésére, problémáinak javítására. http://www.mnvh.eu/sites/ default/files/LEADER munkacsoport hattertanulmany.pdf.

(17) Lukovich T. (2004): Közösségi részvétel, közösségi tervezés. In: Település- és városszociológia (Szerk. Csizmady A. - Husz I.). Gondolat Kiadó, Budapest. 182-206. pp.

(18) Németh S. (2009): Az integrált és komplex vidékfejlesztés 2007-2013. A falu, 24. évf. 4. sz. 77-90. pp.

(19) Ray, C. (1999): Endogenous Development in the Era of Reflexive Modernity. Journal of Rural Studies, Vol. 15. No. 3. 257-267. pp.

(20) Rechnitzer J. (1994): Az erőforrások, áruk mobilitása; a gazdasági jelenségek terjedése a térben. In: Fejezetek a regionális gazdaságtan tanulmányozásához (Szerk. Rechnitzer J.). MTA Regionális Kutatások Központja, Győr-Pécs. 103-141. pp.

(21) Shortall, S. - Shucksmith, M. (2001): Rural development in practice: issues arising in Scotland and Northern Ireland. Community Development Journal, Vol. 36. No. 2. 122-133. pp.

(22) Shucksmith, M. (2000): Endogenous Development, Social Capital and Social Inclusion: perspectives from leader in the UK. Sociologia Ruralis, Vol. 40. No. 2. 208-218. pp.

(23) Szörényiné Kukorelli I. (2005): A fenntartható fejlődés stratégiai elemei a rurális térségekben. Tér és Társadalom, 19. évf. 3-4. sz. 111-137. pp. 
